\title{
ASSOCIATION BETWEEN GESTATIONAL AGE AND ASPHYXIA IN INFANTS IN KARANGANYAR HOSPITAL, CENTRAL JAVA
}

\author{
Yulita Endah Mayaningrum¹), Heni Puji Wahyuningsih²), \\ Nining Wiyati²) \\ 1)Masters Program in Public Health, Universitas Sebelas Maret \\ ${ }^{2)}$ Study Program in Midwifery, Health Polytechnics Ministry of Health Yogyakarta
}

\begin{abstract}
Background: Asphyxia has been hypothesized with hemostatic abnormalities in later stage of life. Perinatal asphyxia can occur due to maternal condition during pregnancy, uterine, or placenta and umbilical cord conditions, and prematurity. The purpose of this study was to examine the association between gestational age and asphyxia in infants in Karanganyar Hospital, Central Java, Indonesia.

Subjects and Method: A case control retrospective study was conducted in Karanganyar, Central Java, in January 2017. A sample of 204 infants was selected for this study. The study subjects were divided into two groups: (1) 102 infants with asphyxia (case group) and (2) 102 infants without asphyxia. The dependent variable was asphyxia. The independent variable was gestational age. The data were obtained from medical record. The data were assessed using Chi-square.

Results: Gestational age $<37$ weeks or $>42$ weeks increased the risk of asphyxia and it was statistically significant $(\mathrm{OR}=3.42 ; \mathrm{p}=0.003)$.

Conclusion: Gestational age $<37$ weeks or $>42$ weeks increases the risk of asphyxia.
\end{abstract}

Keywords: asphyxia, gestational age, maternal age, parity

Correspondence:

Yulita Endah Mayaningrum. Masters Program in Public Health, Universitas Sebelas Maret. Jl. Ir. Sutami 36A, Surakarta 57126, Central Java. Email: yulita.maya95@gmail.com. Mobile: +6285817887585 